\title{
GROWTH PERFORMANCE OF EEL (ANGUILLA ANGUILLA), NILE TILAPIA (OREOCHROMIS NILOTICUS) AND GREY MULLET (MUGL CEPHALUS) CULTURED IN CAGES UNDER TWO FEEDING SYSTEMS
}

\author{
N. F. Abdel-Hakim ${ }^{1}$, M. N. Bakeer ${ }^{2}$ and M. A. Soltan ${ }^{3}$ \\ 1- Faculty of Agriculture, Al-Azhar University, 2-Central Laboratory for Aquaculture Research, \\ Abassa, Sharkia Governorate, Egypt, 3- Faculty Agriculture, Moshtohor, Zagazig University, \\ Banha Branch
}

\section{SUMMARY}

The present experiment was carried out during one growing season for 240 days in cages. The objective of the study was to investigate growth performance of elvers reared in cage in polyculture system with Nile tilapia and mullet using a commercial diet plus trash fish under the Egyptian conditions. Also the study aimed to develop a guideline for fish farmers to improve their production level. The three treatments applied were commercial diet containing ( $45 \%$ crude protein) plus trash fish (Tr1), commercial diet (20\% crude protein) plus trash fish (Tr2) and the same diet as (Tr2) but without eel stock $(\operatorname{Tr} 3)$. Each treatment was performed in triplicates. Cages used in this study were $3 \times 5 \times 5 \mathrm{~m}^{3}$ in diameters and stocked with 500 eel elvers ( $35 \mathrm{~g}$ average weight), 2000 Nile tilapia ( $25 \mathrm{~g}$ average weight) and 1000 Grey mullet with an average weight of $22 \mathrm{~g}$ at the experimental start except the Tr3, which was stocked with tilapia (2000) and mullet (1000) without eels and received the same dietary treatment as in $\operatorname{Tr} 2$. Fish of both treatments were fed on the commercial diets plus the trash fish at a rate of 2 to 1 according to the fish biomass of each cage. Results obtained can be summarized as follows: 1- Final averages of body weight for eel, Grey mullet and Nile tilapia in treatment 1(commercial diet $45 \%$ crude protein plus trash fish) were significantly higher than their corresponding species in the other treatments. 2- Final fish weights of eel, Nile tilapia and Grey mullet per cage in treatment 1 were $90.3,399$ and $170.2 \mathrm{Kg}$, respectively, which were higher by $6.7,18$ and $13.5 \%$ than that obtained in the other treatments. 3- Net returns in LE per cage were 2010.7,2320.3 and 1187.4 LE for treatments $\operatorname{Tr} 1, \operatorname{Tr} 2$ and $\operatorname{Tr} 3$, respectively. Based on the results obtained in this study, a polyculture of eel, Nile tilapia and Grey mullet could be applied in cages using a mixture of commercial diet containing $45 \%$ protein with trash fish at a ratio of 2 to 1 for best yield and growth performance. However the highest net returns were achieved using the $20 \%$ protein diet with trash fish due to the lower costs of the diet.

Keywords: Cage culture, eel, tilapia, mullet

\section{INTRODUCTION}

The family (Anguilla) comprises a single genus of 16 species of freshwater eels; from these species only one of them is known in Egypt as Thobban El-samak Anguilla anguilla. The species known in Egypt lakes the pelvic fins. They are distributing along the River Nile especially the north Delta region near lakes of Brollos, Manzalah, Edco, Maryout and coastal Lagoons (GAFRD, 1997).

The extensive culture in the Mediterranean Lagoons is based on elvers, which are allowed to enter the impounded areas through the manipulation of tidal flows and which are grown in the fertile lagoon waters (Pillay, 1990).

In Egypt, elvers are available at pump station No. 1 1; Borollos, Gamasa and El-Max in Alexandria. The Egyptian eel is a fish species of high value especially in the Japanese and European markets. Eel farms will be successful in Egypt because of the following reasons 1- Egypt climate is very suitable for eel farming. 2- production costs in Egypt is lower than in Japan and Taiwan (GAFRD, 1997). Family Anguillidae had varies feeding rates according to water temperature, size and food type. Kafuku and Ikenoue (1983) reported that the optimum temperature for eels of $10 \mathrm{gm}$ body weight was $25 \mathrm{C}^{\circ}$. They added that the ideal feeding rate for small elvers is about $6-8 \%$ of the total biomass; $2-6 \%$ for young eels and $1-3 \%$ for the adults daily, when fed on commercial diets containing $20-30 \%$ crude protein and boiled trash tish. Concerning the culture of tilapia and mullet in floating cages, Abdel-Hakim and Sherif (1999) showed that tilapia could be cultured together with mullet and common carp in floating cages throughout the period from March to November in Egypt. They reported that the expected 
production from tilapia; mullet and common carp is estimated by $756 ; 162$ and $227 \mathrm{Kg}$, respectively, when they stocked together in floating cages of a total volume of $24 \mathrm{~m}^{3}$ at densities of $70 ; 45$ and 15 fingerlings of tilapia; mullet and carp $\mathrm{m}^{3}$, respectively. The same authers reported also that a diet containing $25 \%$ protein is required to produce a feed conversion ratio of $1: 2$ during the production period. The present study was carried out to investigate growth performance of elvers reared in cage culture in polycultre system using a commercial diet containing trash fish under the Egyptian conditions. Also the study aimed to develop a guideline for eel farmers to improve their production level.

\section{MATERIALS AND METHODS}

This experiment was carried out in the branch of the River Nile (Rasheed branch) at Kafr-El-sheikh Governorate, Egypt for eight months (one growth season). The water at the experimental side is considered as freshwater with an average salinity ranging between 3.2 to $4.1 \mathrm{~g} / \mathrm{L}$. The experiment started at $1^{\text {th }}$ April and lasted at the end of November 1999.

\section{Experimental cages}

Nine cages each of $3 \times 5 \times 5 \mathrm{~m}^{3}$ in diameters with a total water volume of $75 \mathrm{~m}^{3}$ each were used in this study. The Nine cages represented three treatments in triplicates. The water depth in the area of the present study was about $5 \mathrm{~m}$ and fluctuated in a range of $+2 \mathrm{~m}$ due to the tide of the Mediterranean Sea in this area. The sides of the cage were surrounded with nets to the bottom of the river and bottom of the cage is made of nets of the same mesh.

The nets used in the construction of the experimental cages were of a 9mm-inesh size. The Cages were fixed from the corners with wood bars to maintain the frame of the cage. The first three cages (replicates) of the first treatment group were stocked with 500 elvers; 2000 Nile tilapia and 1000 Grey mullet per cage and fed on a commercial diet containing $45 \%$ crude protein (Table2) plus trash fish at a ratio of 2 to I (TrI). The second three cages ( $\operatorname{Tr} 2)$ were stocked with the same fish species at the same rates and fed on a diet containing $20 \%$ crude protein (Table2) plus the trash fish at the ratio $2: 1$. Cages of third treatment (Tr3) were stocked with Nile tilapia (2000) and Grey mullet (1000) per cage without eel and fed the same diet as ( $\operatorname{Tr} 2)$ with trash fish at the same ratio. Fish of the experimental cages were fed on the diets at a rate of $5 \%$ of the fisli biomass divided into portions to be fed three times daily. The feeding times were at 10 a.m. 12 and 2 p.m. daily. The experimental diets were mixed daily with minced boiled trash fish at a ratio of 2:1.

\section{Experimental fish}

Cages were stocked in a polyculture system with eel species (Anguilla anguilla), which represents the carnivorous fish species (fed on insects, crustaceans and boiled trash fish or commercial formulated diets containing $40-50 \%$ protein at least), Nile (ilapia species (Oreochromis niloticus) which represents the detritophagic species (fed on zooplankton, plant detritus, zoobenthos and commercial diet) and Grey mullet species(Mugil cephahts)a detritophagic species (fed on zooplankton, detritus and commercially formulated diet). Fish used in this study and their stocking rates are shown in the Table (1).

Table 1. Fish species and stocking rate of the experimental cages

\begin{tabular}{|c|c|c|c|c|c|}
\hline Common name & Scientific name & \multicolumn{3}{|c|}{ Stocking rate/cage } & Initial body Weight (g) \\
\hline & & Tr1 & Tr2 & Tr3 & \\
\hline Thobban El-samak & Anguilla anguilla & 500 & 500 & - & 35 \\
\hline Nile tilapia & Oreochromis niloticus & 2000 & 2000 & 2000 & 25 \\
\hline Grey mullet & Mugil cephaltis & 1000 & 1000 & 1000 & 22 \\
\hline
\end{tabular}

Samples and measurements

Body weights $(\mathrm{g})$ were measured biweekly till larvesting in a random sample of (50. fish of eels, 100 fish of Grey mullet and 200 fish of Nile tilapia) in each cage. The body weights were recorded by weigling the whole sample. Initial body weights to the nearest gram were recorded at the time of cage stocking. Water temperature, $\mathrm{pH}$ and $\mathrm{O}_{2}$ contents were measured daily at $12 \mathrm{p.m}$. using temperature and dissolved oxygen meter (YSI model 57) and $\mathrm{pH}$ meter (model Corning 345). Determinations of 
water quality parameters (salinity, ammonia) were carried out every two weeks according to the methods described by Boyd (1979).

Table 2, Composition of the commercial diets used in the study

\begin{tabular}{lclc}
\hline Ingredients & Diet $145 \% \mathrm{CP})$ & \multicolumn{1}{c}{ Ingredients } & Diet $2(20 \% \mathrm{CP})$ \\
\hline Meat meal $(54 \% \mathrm{CP})$ & $30 \%$ & Meat meal $(54 \% \mathrm{CP})$ & $5 \%$ \\
Fish meal $(72 \% \mathrm{CP})$ & $30 \%$ & Fish meal $(72 \% \mathrm{CP})$ & $7 \%$ \\
Yellow corn $(9 \% \mathrm{CP})$ & $25 \%$ & Yellow corn $(9 \% \mathrm{CP})$ & $43 \%$ \\
Soybean meal $(44 \% \mathrm{CP})$ & $10 \%$ & Wheat bran(15.7\%CP) & $15 \%$ \\
Fat & $5 \%$ & Rice bran $(13 \% \mathrm{CP})$ & $20 \%$ \\
& & D.C.M* $(40 \% \mathrm{CP})$ & $10 \%$ \\
Total & $100 \%$ & & $100 \%$ \\
Calculated & 44.45 & Crude protein & 20.56 \\
Crude protein & 1.26 & Lysine & 0.54 \\
Lysine & 0.53 & Methionine & 0.29 \\
Methionine & 4155 & & 3728.8 \\
GE** Kcal $/ \mathrm{Kg}$ diet & & & \\
Analyzed & 44.10 & Crude protein CP & 19.8 \\
Crude protein CP & 11.16 & Ether extract EE & 6.2 \\
Ether extract EE & 4.30 & Crude fibers CF & 6.68 \\
Crude fibers CF & & & \\
\hline
\end{tabular}

"Decorticated cottonseed meal.

The chemical analyses of tested diets of fish were carried out according to the AOAC. (1990) methods. Samples were collected from different sites of the experimental cages randomly to represent the water of the whole cage. The economical evaluation of results was carried out according to the market prices in 1999 for the diets, trash fish, labors, fish fingerlings and marketable fish in LE.

Statistical analysis

Statistical analysis of data was carried out according to Harvey computer program (1990).

\section{RESULTS AND DISCUSSION}

Water quality parameters:

Averages of water quality parameters measured during this experiment are illustrated in Table 3. The averages of water pH values had ranged between 7.85 to 8.35 degree which indicate the suitability of the water $\mathrm{pH}$ for the activities of the fish species cultured in the experimental cages. The dissolved oxygen contents of the water had ranged between 7.10 to $8.2 \mathrm{mg} / \mathrm{l}$ on the average during the experimental period and were in the permissible levels of fisl culture. Water total ammonia $(\mathrm{mg} / \mathrm{l})$, Salinity $\mathrm{g} / \mathrm{l}$ and temperature ${ }^{\circ} \mathrm{C}$ were found to be 0.6 to $1.3 \mathrm{mg} / \mathrm{L}, 3.2$ to $4.1 \mathrm{~g} / 1$ and 28.06 to $30.7^{\circ} \mathrm{C}$, respectively. (Table 3), which indicate the suitability of cage water for fish growth and development. These results are in accordance with those reported by El-Gendy (1998), Abdel- Hakim et al.(1999) and Abdel- Hakim et al. (2000). Results of Table 3 are also in agreement with those reported by Noda (1977) and Kafuku and Ikenoue (1983), who showed that the optimum temperature is $25^{\circ} \mathrm{C}$ and above for the 10 grams eels. Also, Baradach et al.(1972) reported that the optimum growth of eels could be achieved with water temperatures ranging between $20-28^{\circ} \mathrm{C}$.

Table 3. Averages of water quality parameters of cages during the experimental period (240

\begin{tabular}{lccccc}
\multicolumn{2}{c}{ days) } & \multicolumn{1}{c}{} \\
\hline Treatments & PH & D.0 m//L & Anmonia mo/L & Salinity & Temperature e $^{\circ}$ \\
\hline Tr1 & $8.15 \pm 0.24$ & $8.20 \pm .34$ & $0.60 \pm 0.06$ & $3.3 \pm 0.04$ & $28.06 \pm 0.73$ \\
Tr2 & $8.35 \pm 0.24$ & $7.80 \pm .34$ & $0.75 \pm 0.05$ & $4.1 \pm 0.07$ & $28.62 \pm 0.74$ \\
Tr3 & $7.85 \pm 0.24$ & $7.10 \pm .34$ & $1.30 \pm 0.07$ & $3.2 \pm 0.08$ & $30.70 \pm 0.65$ \\
\hline
\end{tabular}

\section{Growth performance}

Averages of initial body weights of eels in treatments $\operatorname{Tr} 1$ and $\operatorname{Tr} 2$ were 35.2 and $35.8 \mathrm{~g}$, respectively and differences among the two groups stocked with eels were insignificant (Table 4). At the end of the experimental period, averages of final weights for both groups cited above were 200.8 and $188.12 \mathrm{~g}$., respectively. The analysis of variance for results indicates that the $\operatorname{Tr} 1$ had significantly $(P<0.05)$ heavier final weights of eels compared to $\operatorname{Tr} 2$. These results indicate that feeding the 
growing eels on a diet containing $45 \%$ crude protein improved significantly the final weights compared to the diet containing $20 \%$, since the amount of trash fish fed was almost similar in both groups. The superiority of group $\operatorname{Trl}$ in final body weight may attributed to the fact that the ration fed to this group may cover the nutritional requirements from lysine and methionine (Table 2). These results are in agreement with the findings of Noda (1977) and Kafuku and Ikenoue (1983), who reported that final body weights of eels improved when elvers were fed on diets containing $30 \%$ protein with boiled trash fish compared to $20 \%$ protein level with trash fish. In this connection, Ezzat et al. (1984), reported that the growth rate of eels (Anguilla anguilla) in Lake Manzala is highest by the end of its second year of fresh water life. Results of Usui (1991) showed that cultured eels in Japan are fed on artificial diet made of chiefly fishmeal with added carbolydrates and consists of about $52 \%$ protein, $24 \%$ carbohydrate, $10 \%$ water, $4 \%$ fat and $10 \%$ ash. As presented in Table (4), average of daily gains in weight for eels in $\operatorname{Trl}$ and $\operatorname{Tr} 2$ were 0.69 and $0.63 \mathrm{~g}$, respectively and the statistical evaluation of the results indicate the superiority $(\mathrm{P}<0.05)$ of $\mathrm{Tr} 1$ in average daily gain compared to the $\mathrm{Tr2}$. Data in the same Table shows also that the survival rate of eels for both treatment groups was $90 \%$, which reflect 10 influence of the dietary treatments on this trait. Results revealed also that the total productions of eels per cage at harvesting for Tr1 and Tr2 were 90.3 and $84,6 \mathrm{Kg}$, respectively (Table 4). These results indicate that feeding cels in polyculture system using fixed cages on a diet containing $45 \%$ protein with trash fish increased the total production of eels by about $6.7 \%$ compared
to those fed on a diet containing $20 \%$ protein with trash fish.

As presented in Table 4, averages of initial weiglts of Nile tilapia for $\operatorname{Tr} 1$; $\operatorname{Tr} 2$ and $\operatorname{Tr} 3$ were 25.4; 25.7 and $25.8 \mathrm{~g}$, respectively, and differences in initial weights among the treatment groups were insignificant. Results of the same Table show that the averages of final weight of the same treatment groups cited above were $210 ; 193$ and $185 \mathrm{~g}$, respectively. The statistical evaluation of results indicate that group $\operatorname{Tr} 1(45 \%$ prolein dict) showed significantly $(\mathrm{P}<0.05)$ heavier final weights compared to $\operatorname{Tr} 2$ and $\operatorname{Tr} 3 \quad(20 \%$ protein diet), however differences in sinal weights among the (last two groups ( $\operatorname{Tr} 2$ \& Tr3) were insignificant. The same trend was observed with the results of average daily gain (Table 4). These results are in agreement with the findings of Cruz and Laudenica (1976); Hughes (1977); Viola and Zohar (1984), who showed that increasing the protein level in diets of tilapia from 25 to 30 or $35 \%$ increased significantly body wcight and growth ratc. Also Wang et al: (1985), reported that increasing the protein level from 13 to $40 \%$ in tilapia diets increased fish growth performance and group fed on the $30 \%$ protein diet obtained the best performance. Reccitly, Abdcl-Hakim and Moustafi (2000) reported that final body weight and the daily gains of Nile tilapia increased significantly with each increase in the dietary protein level fed from 20 to 24,28 and $32 \%$. Results of survival rate of tilapia (Table 4) show that the survival ranged between 93 to $95 \%$ which is considered as a very good survival rate. Tilapia total productions per cage at harvest were found to be $399,358.9$ and $351.5 \mathrm{Kg}$. for the $\operatorname{Tr} 1, \operatorname{Tr} 2$ and $\operatorname{Tr} 3$ group, respectively. These results indicate that tilapia in $\operatorname{Tr} 1(45 \%$ protein + trash fish) with inullet and eels produced $13.5 \%$ more weight on the average compared to $\operatorname{Tr} 3(20 \%$ protein +trash fisli) with mullets and without eels.

These results are in partial agreement with the findings of Abdel-Hakin and Moustara (2000) who showed that the total production of tilapia cultured in cages $\left(1 \mathrm{~m}^{3}\right)$ increased from 14.3 to $18.4,20.9$ and $22.7 \mathrm{Kg}$ as the dietary protein levels increased from 20 to 24,28 and $32 \%$, respectively. Concerning mullet, averages of initial weights had ranged between 22 to $22.5 \mathrm{~g}$ at the experimental start with insignificant differences in intial weights among the treatmen groups (Table 4). At harvest; mullei final body weights for $\operatorname{Tr} 1, \operatorname{Tr} 2$ and $\operatorname{Tr} 3$ were 185,168 and $155 \mathrm{~g}$, respectively (Table 4). Analysis of variance of final body weiglts indicated that $\operatorname{Trl}$ liad significantly $(\mathrm{P}<0.05$ ) heavier final weights of mullet compared $10 \mathrm{Tr} 2$ and $\operatorname{Tr} 3$. Results revealed also that mullet in $\operatorname{Tr} 2$ showed heavier final weiglts compared to $\operatorname{Tr} 3$, however the differences were insignificant. The same trend was observed in averages of daily gains where that of $\operatorname{Tr} \mathrm{l}$ was significantly $(\mathrm{P}<0.05)$ ligher than that of $\operatorname{Tr} 2$ and $\operatorname{Tr} 3$ (Table 4). These results are in partial agreement with those reported by Papapreskeva and Alexis (1986), who showed that the growth of Mugil capito, $2.2 \mathrm{~g}$, increased with increasing protein contents of the diet from 12 to $24 \%$, while beyond this level it was decreased. Also Ojaveer et at (1996) observed decreases in growth of Grey mullet, $14 \mathrm{~g}$, in response to increasing dietary protein level when they used 38,49 and $60 \%$ protein levels with $4.54,5,02$ and $5.02 \mathrm{Kcal} / \mathrm{g}$ as gross energy.

As presented in Table 4 , averages of survival rates for $\operatorname{Tr} 1$, $\operatorname{Tr} 2$ and $\operatorname{Tr} 3$ were 92,91 and $93 \%$ respectively, which lay within the acceptable range of cage culture. Averages of total mullet yield per. cage at harvest for the same experimental groups cited before were $170.2,152.8$ and $144.1 \mathrm{Kg}$,
respectively (Table 4 ). 


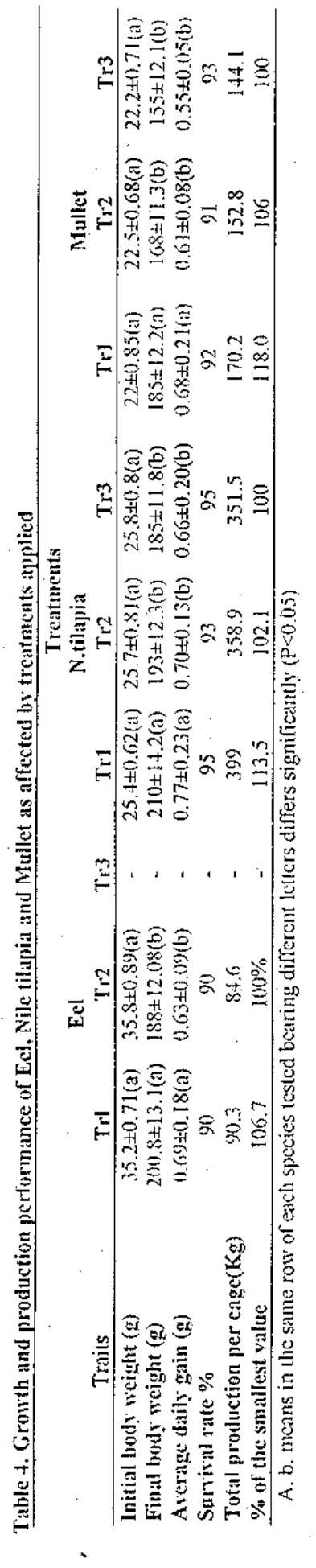


These results indicate that $\operatorname{Tr} 1$ produced $18 \%$ more mullet over $\operatorname{Tr} 3$, while the $\operatorname{Tr} 2$ produced only $6 \%$ over $\operatorname{Tr} 3$ (Table4). In general, results presented in Table (5) show that the total cage productions from the species cultured were $659.5,596.3$ and $495.6 \mathrm{Kg}$ for $\operatorname{Tr} 1, \operatorname{Tr} 2$ and $\operatorname{Tr} 3$, respectively. These results may indicate that $\operatorname{Tr} 1$ (diet containing $45 \%$ crude protein + rash fish) gave the highest production per cage, however the costs remain a limiting factor for such feeding system.

Table 5. Total production per cage $(\mathrm{Kg})$

\begin{tabular}{cccccc}
\hline & Eel & Tilapia & Mullet & Total & \% of the smallest value \\
\hline Tr1 & 90.3 & 399 & 170.2 & 659.5 & $133.07 \%$ \\
& $13.7 \%$ & $60.5 \%$ & $25.8 \%$ & $100 \%$ & \\
Tr2 & 84.6 & 358.9 & 152.8 & 596.3 & $120.3 \%$ \\
& $14.2 \%$ & $60.2 \%$ & $25.6 \%$ & $100 \%$ & \\
Tr3 & -- & 351.5 & 144.1 & 495.6 & $100 \%$ \\
& -- & $70.9 \%$ & $29.1 \%$ & $100 \%$ & \\
\hline
\end{tabular}

Economic Efficiency

As presented in Table 6, total costs per cage including the variable, fixed, taxes and the interest on working capital in LE were found to be 3216.4, 2447.4 and 1788.2 LE for the Tr1, Tr2 and Tr3 groups, respectively. These results indicate that the total costs of $\operatorname{Tr} 3$ were the lowest due to the fact that this treatment was not provided with elvers and was fed on the diet containing $20 \%$ crude protein which reduced its total costs. On the other hand, the $\operatorname{Tr} 2$ showed $36.9 \%$ higher costs than the $\operatorname{Tr} 3$ due to the costs of elvers and feeds which were fed at higher rates compared to $\mathrm{Tr} 3$. As shown in the same Table, Trl had $79.9 \%$ higher total costs than the $\operatorname{Tr} 3$ because of the fact that this group was stocked with elvers and fed on a diet containing $45 \%$ protein which is more expensive compared to that fed in $\operatorname{Tr} 2$ and $\operatorname{Tr} 3$.

Table 6. The effect of the experimental diets on economic efficiency LE/cage

\begin{tabular}{|c|c|c|c|}
\hline \multirow[t]{2}{*}{ Ilems } & \multicolumn{3}{|c|}{ Treatments } \\
\hline & 1 & 2 & 3 \\
\hline \multirow{2}{*}{\multicolumn{4}{|c|}{$\begin{array}{l}\text { (1) Variable costs, LE/cage }\left(75 \mathrm{~m}^{3}\right) \\
\text { a-Costs of fish fingerlings: }\end{array}$}} \\
\hline & & & \\
\hline Eel & 500 & 500 & \\
\hline Tilapia & 200 & 200 & 200 \\
\hline Mullet & 350 & 350 & 350 \\
\hline \multicolumn{4}{|l|}{ b-Fccds: } \\
\hline Commercial diets & 866.7 & 400 & 333.3 \\
\hline Trash fish & 433.3 & 200 & 166.7 \\
\hline c-Labor: & 266.7 & 266.7 & 266.7 \\
\hline \multicolumn{4}{|l|}{ d- Fixed costs, LE/cage $\left(75 \mathrm{~m}^{3}\right)$ : } \\
\hline Depreciation ( cages \& materials) $20 \%$ & 111 & 111 & 111 \\
\hline Taxes .. & 200 & 200 & 200 \\
\hline e-Tolal operating costs(Variable \& fixed) & 2927.7 & 2227.7 & 1627.7 \\
\hline f- Interest on working capital * & 288.8 & 219.7 & 160.5 \\
\hline g-Total costs & 3216.5 & 2447.4 & 1788.2 \\
\hline$\%$ of the smallest value of total costs & $179.9 \%$ & $136.9 \%$ & $100 \%$ \\
\hline \multicolumn{3}{|l|}{ (2)Return } & Fish sales \\
\hline Eel & .1806 .7 & 1692 & \\
\hline Tilapia & 2314.2 & 2082 & 2038.7 \\
\hline Mullet & 1106.3 & 993.6 & 936.9 \\
\hline h-Total return (L.E.)** & 5227.2 & 4767.64 & 2975.6 \\
\hline (h-g)Ne1 return, LE/cage $\left(75 \mathrm{~m}^{3}\right)$ & 2010.7 & 2320.3 & 1187.4 \\
\hline$\%$ of the smallest value of net return & $169.3 \%$ & $192.4 \%$ & $100 \%$ \\
\hline$\%$ Net returns to total costs & $62.5 \%$ & $94.8 \%$ & $66.4 \%$ \\
\hline
\end{tabular}

Net returns in LE per cage were 2010.7, 2320.3 and 1187.4 LE for treatments $\operatorname{Tr} 1, \operatorname{Tr} 2$ and $\operatorname{Tr} 3$, respectively (Table 6). Percentages of net returns to total costs were $62.5,94.8$ and $66.4 \%$ for $\operatorname{Tr} 1, \operatorname{Tr} 2$ and $\operatorname{Tr} 3$, respectively (Table 6 ). 
Under the condition of this experiment, results show in general that cages stocked with eel, tilapia and muIlet and fed on a diet containing $20 \%$ protein plus trash fish at a rate $2: 1(\operatorname{Tr} 2)$ was economically more efficient than the cages stocked with the same fish species at the same rates and fed the diet containing $45 \%$ protein plus trash fish ( $\operatorname{Tr} 1)$. These results may led us to recommend the culture of eels with tilapia and mullet in cages using artificial diets containing at least $20 \%$ protein plus trash fish at a ratio of 2 to 1 for the best net returns. In this connection, Abd El-Maksoud (2000). reported that feeding Grey mullet raised in earthen ponds on a diet containing $29 \%$ protein resulted in higher growth performance, decreased feeding costs and increased profit.

\section{REFERENCES}

Abdel-Hakim, N.F and Moustafa,S.T.,2000. Performance of Nile tilapia (Oreochromis niloticus) raised in cages as affected with stocking density and dietary protein level. Egyptian Journal of Aquatic Biology and Fisheries. Vol.4, No2: 95-116.

Abdel-Hakim, N. F; Bakeer, M. N and Soltan, M.A.,2000. Effect of integrated fish culture with farm Animals on water quality parameters and plankton communities.(in press).

Abdel-Hakim, N. F; Bakeer, M.N and Soltan, M.A., 1999. Integrated fish culture with farm Animals. Annals of Agricultural Science, Moshtohor. Zagazig University (Banha-Branch). Vol.37 Number 2 June1999.

Abdel-Hakim, N.F and Sherif El.Y., 1999. Technical economic study for aquaculture on floating cages. J. Agric. Sci. Mansoura Univ., 24(10) 5677- 5686.

Abd El- Maksoud, A.M.S., 2000. Response of Grey mullet (Mugil cephalus L.), Cultured in earthen ponds, to diets of varying protein levels. Egyptian Journal Anim. Prod. 37 (1): 57-66.

Association of Official Analysis Chemists (AOAC), 1990. Official methods of Analysis, 15 ${ }^{\text {th }}$ Edo, PP 1298, Virginia.

Baradach, J. E., Rylher, J. H and Mclarney, W. O., 1972. Aquaculture. The farming and husbandry of freshwater and marine organisms. Wiley- Interscience. $868 \mathrm{P}$.

Boyd, C.E., 1979. Water quality in warm water fishponds.Ed. Claude E. Boyd. Third printing, 1984.Pub, Auburn Univ., Agri.Exp. Station, AID/Dsan-G.G. 0039.pp.359.

Cruz, E.M.and Laudencla. L., 1976. Preliminary study on the protein requirements of Nile tilapia (Oreochromis niloticus) fingerlings. IFP. Tech. Rept- No 10, $2^{\mathrm{sl}}$ half CY 1976, up. Diliman, Quezon cily Philippines, 117-129.

El-Gendy, M.U. 1998. Effect of Aquculture systens on pond productivity and economical erficicncy. M.Sc. Thesis. Faculty of Agriculture. Al-Azhar Univ.

Ezzat, A; AL-Kholy, A. A. and EL-Scrafy, S., 1984. Agc and growth of Anguilla Anguilla (L) in lakc Manzalae, Egypt.Bull. Inst. Oceanogr. \& Fish. ARE, 10: 81-91.

G.A.F.R.D. General Authority for Fish Resources Development, 1997. Cairo, Egypt. Annual report.

Huglies, D.C., 1977. Progress Report on fisheries Development in El Salvador Int Center for Aquaculture, Auburn. Univ., Auburn, Alabama, Res. And Dev., 115 PP.

Harvey. W.R., 1990, User's guide for LSMLMW. Mixad model least-squares and aximum likelihood computer prog. Ohio states University. Columbus, USA.

Kafuku, T, and Ikenoue, H., 1983. Modern Metlods of Aquaculture in Japan. Esscvier Scientific Publishing Company. Amsterdam- Oxford-New York. 216 P.

Noda, U., 1977. Fisheries in Japan Eel. Kohoka Publishing Company, LTD, Tokyo. 225 P

N.R.C., 1983. Nutrient Requirements of warm water fishes and shell fishes. National Researcli Council, Nati. Acad. SCI. Washington. D.C. USA.

Ojaveer, H., Morris, P.C., Davies, S.J and Russell, P.,1996. The response of thick-Lipped Grey mullet, Chelon labrosus (Risso), to diets of varied protein-to-Energy ratio. Aquaculture Research 27,8, 603-612.

Papapareskeva-papoutsoglou E. and Alexis, M.N., 1986. Protein requirements of Young Grey mullet, Mugil capito. Aquaculture 52, 105-115.

Pillay, T.V.R, 1990. Aquaculture Principles and Practices Book, 351-353 PP.

Usui, A. 1991: Eel Culture. Fishing News Books, Oxford.

Viola, S. and Zolar, G., 1984. Nutrition studies with marked size hybrids of tilapia (Oreochromis) in intensive culturc. Bamidgeh: 36(1): 3-15.

Wang, K.W.; Takeuchi, T. and Watanabe, T. (1985). Optimum protein and digestible energy levels in diet for Tilapia nilotica. Bull. Soc. Sci, fish.S1 (1): 141-146. 